\title{
Creatine Kinase in Serum after Uterus Contraction Produced by Oxytocin
}

It has been reported by others, and confirmed by our own observations that creatine kinase is increased in serum immediately after delivery ${ }^{1,2}$. However, it is not known if the observed modification is due to the contractions of the uterus or to the contractions occurring in the striated muscle during labour. Therefore the phenomenon has been investigated again, measuring creatine kinase in human serum before and after uterus contraction produced by oxytocin.

Creatine kinase has been determined in the serum of 6 women subjected to Caesarean section before operation and $1 \mathrm{~h}$ after uterine contraction elicited by $\mathrm{i} . \mathrm{v}$. injection of $5 \mathrm{U}$ of synthetic oxytocin (Sandoz, Basel); in 3 women on the ninth day after total hysterectomy and bilateral salpingo-oophorectomy, also before and after administration of oxytocin; and in 4 women before and after a

Creatine kinase in human serum before Caesarean section and $1 \mathrm{~h}$ after treatment with oxytocin

\begin{tabular}{|c|c|c|}
\hline \multirow[t]{2}{*}{ Case } & \multicolumn{2}{|c|}{$\mu$ moles creatine phosphor. $/ 1$ serum $/ \mathrm{h}$} \\
\hline & bcfore & after \\
\hline 1 & 26.2 & 106 \\
\hline 2 & 11.0 & 60 \\
\hline 3 & 11.2 & 54 \\
\hline 4 & 11.0 & 48 \\
\hline 5 & 16.4 & 50 \\
\hline 6 & 13.2 & 60 \\
\hline
\end{tabular}

gynaecological operation. Creatine kinase was assayed with the method of ENNOR and ROSEMBERG ${ }^{3}$, as modified by HuGHES ${ }^{4}$, in serum obtained centrifuging heparinized blood.

In all cases administration of oxytocin to women subjected to Caesarean section gives rise to a marked increase of serum creatine kinase. In the cases in which uterus has been previously removed, treatment with oxytocin has no effect on serum creatine kinase. During other gynaecological operations, where there is no uterine contraction, only slight modifications are observed.

From the results obtained it may be concluded that a prolonged contraction of the uterine muscle gives rise to a high increase of serum creatine kinase.

Riassunto. In donne sottoposte a taglio cesareo la contrazione dell'utero provocata da ossitocina causa un netto aumento della creatinacinasi del siero. Con lo stesso trattamento con ossitocina l'enzima non varia in donne prive di utero.

A. LANZA

Institute of Biochemistry of the University and

St. Anna Obstetric and Gynaecologic

Hospital (I Div.) Torino (Italy), 5 December 1967.

1 G. Benfatto and S. PACI, Clin. Ginec. 1, 433 (1959).

2 C. Franza and A. Palmieri, Archo Ostet. Ginec. 69, 270 (1964).

3 A. H. Ennor and H, Rosemberc, Biochem. J. 203, 57 (1954).

4 P. B. Hugnes, Clinica chim. Acta 7, 597 (1962).

\section{Signs of Cerebral Hypoxia in Hyperventilation}

Although measurements of cerebral circulation (CBF), cerebral electrical activity or cerebral $\mathrm{O}_{2}$ tension during marked hyperventilation suggest that the CBF is reduced to a degree which leads to cerebral hypoxia ${ }^{1,2}$, conclusive proof thereof has been lacking. Such proof evidently requires measurements of the redox state of suitable intracellular redox systems ${ }^{3,4}$. In the present paper a report is given on measurements of cerebrospinal fluid (CSF) and cerebral tissue concentrations of lactate and pyruvate during varying degrees of hyperventilation in anaesthetized cats. These results suggest the presence of cerebral hypoxia at arterial $\mathrm{CO}_{2}$ tensions below $20 \mathrm{~mm} \mathrm{Hg}$.

Methods. Cats were anaesthetized with i.p. phenobarbital $(100 \mathrm{mg} / \mathrm{kg})$ and tracheotomized. Arterial samples were withdrawn anaerobically from a cannula in one femoral artery, and CSF samples from the suboccipital cistern. Arterial blood was analyzed for $\mathrm{pH}$ and $\mathrm{PCO}_{2}^{8}$. Blood and CSF were collected directly in liquid nitrogen for the subsequent enzymatic analysis of lactate and pyruvate. After taking at least 2 control blood and CSF samples, the animals were either hyperventilated for $60-90 \mathrm{~min}$, or were allowed to breathe $9-15 \% \mathrm{CO}_{2}$ for the same time periods. At the end of the experiments, the brain tissue was frozen in situ with liquid nitrogen which was poured directly onto the exposed dura. The subdural tissue was then chiselled out and the lactate and pyruvate concentrations analyzed enzymatically ${ }^{6}$.
Results. In the Figure, the arterial $\mathrm{CO}_{2}$ tension has been plotted against the CSF lactate concentration and against the CSF lactate/pyruvate ratio. There is a marked increase in the CSF lactate concentration when the arterial $\mathrm{CO}_{2}$ tension is brought below $20-25 \mathrm{~mm} \mathrm{Hg}$. At the same $\mathrm{CO}_{2}$ tensions, the CSF lactate/pyruvate ratio is progressively increased. Essentially the same results were obtained on the brain samples, showing that the direction of changes was the same in both extra- and intracellular spaces, although the lactate and pyruvate concentrations differ between the 2 compartments.

Discussion. It has been pointed out that since the lactate/pyruvate system is coupled to the NADH/NAD ${ }^{+}$

1 S. C. Alexander, P. J. Cohen, H. Wollman, T. C. Smith, M. Rervich and R, A. VAN Der MOLen, Anesthesiology 26, 624 (1965).

2 J. S. Meyer and F. Goton, Archs Neurol. Psychiat, Chicago 3, $539(1960)$.

"H. J. Howorst, Der Reduklionszustand des DiphosphopyridinNukleotidsystems in lebendem Getebe (Dissertation; University of Marburg 1960).

4. H. Wrlliamson, P. Lund and H. A. KreBs, Blochem. J. 103, 514 (1967).

- U. Ponten and B. K. Siesjö, Acta physiol, scand. 67, 129 (1966). - L. Granholm and B. K. Siesjo, Acta physiol scand. 70, 255 (1967). 